\title{
LANGUAGE EXPRESSION TRADERS BUY AND SELL INTERACTIONS IN THE KMGD TEBUIRENG MARKET
}

\author{
Suci Armala', Udjang Pairin M.Basir ${ }^{2}$ \\ 'Pendidikan Bahasa dan Sastra Indonesia, Fakultas Ilmu Pendidikan, Universitas Hasyim Asy'ari \\ ${ }^{2}$ Fakultas Bahasa dan Seni, Universitas Negeri Surabaya
}

Corresponding Author: ${ }^{1}$ Suciarmala10@gmail.com

\begin{abstract}
The purpose of this study is to find and explain the language of traders in the interaction of buying and selling in the Kawasan Makam Gus Dur Tebuireng Jombang (KMGD) market. The research method used is a descriptive qualitative approach. The data collection techniques used were: 1. Technique survey, 2. Recording technique, 3. Listening technique and 4. Note technique. The data analysis technique uses the following techniques: 1. Data collection, 2. Data reduction, 3. Data presentation, 4. Conclusing drawing / verification. In this study, the validity of the data used data triangulation: 1. Technique triangulation, 2. Time triangulation. The results of the research that can be formulated that the language expressions used by merchants are Javanese, Indonesian and Madurese.
\end{abstract}

Keywords: Language Expression, Interaction

\section{UNGKAPAN BAHASA PEDAGANG DALAM INTERAKSI JUAL BELI DI PASAR KMGD TEBUIRENG JOMBANG}

\begin{abstract}
Abstrak
Tujuan penelitian ini yakni untuk menemukan serta menjelaskan tentang ungkapan bahasa pedagang dalam interaksi jual beli di pasar Kawasan Makam Gus Dur (KMGD) Tebuireng Jombang. Metode penelitian yang digunakan yakni pendekatan kualitatif deskriptif. Teknik pengumpulan data yang digunakan: 1. Tekik survey, 2. Teknik rekam, 3. Teknik simak dan 4. Teknik catat. Teknik analisis data menggunakan teknik: 1. Pengumpulan data, 2. Reduksi data, 3. Penyajian data, 4. Conclusing drawing/verification. Pada penelitian dilakukan keabsahan data yang memakai triangulasi data: 1 . Triangulasi teknik, 2. Triangulasi waktu. Hasil penelitian yang dapat dirumuskan bahwa ungkapan bahasa pedagang yang digunakan yakni bahasa Jawa, bahasa Indonesia dan bahasa Madura.
\end{abstract}

Kata Kunci: Ungkapan, Interaksi

\section{PENDAHULUAN}

Variasi bahasa atau ragam bahasa yakni satu bahasan pokok dalam kajian sosiolinguistik, karena variasi bahasa menghubungkan bahasa sosial kemasyarakatan. Pernyataan tersebut sesuai dengan Kridalaksana (Chaer. 2014:61), yang menyatakan bahwa sosiolinguistik merupakan suatu cabang dari linguistik yang berusaha menjelaskan tentang ciriciri variasi bahasa dan menetapkan korelasi ciriciri variasi bahasa tersebut dengan ciriciri sosial masyarakat. Kemudian dengan mengutip pendapat dari Fishman (Chaer. 2014:61) mengatakan bahwa sosiolinguistik ialah sebuah ilmu yang mempelajari ciri dan fungsi perbagai variasi bahasa, serta hubungan diantara bahasa, ciri dan fungsi itu dalam suatu masyarakat bahasa.

Sebagai langue sebuah bahasa memiliki sistem dan subsitem yang dapat dipahami oleh penutur bahasa itu. Namun, ketika penutur bahasa berada dalam masyarakat tutur dan tidak merupakan kumpulan manusia yang homogen, maka wujud bahasa tersebut itu 
konkret dan menjadi tidak seragam. Bahasa itu menjadi beragam atau bervariasi. Terjadinya kevariasian atau keberagaman bahasa bukan hanya disebabkan oleh para penuturnya yg tidak homogen tetapi juga karena kegiatan interaksi sosial yang mereka lakukan seperti interaksi sosial yang terjadi di pasar. Pasar yakni suatu lokasi pertemuan antara para pedagang dan pembeli yang saling melakukan kegiatan transaksi jual beli juga tawar menawar, mulai dari pedagang makanan, pedagang aksesoris, pedagang pakaian dan lain sebagainya. Tentunya dengan interaksi yang terjadi antar pedagang dan pembeli dengan adanya bahasa akan lebih mempermudah mengungkapkan apa yang dipikirkan dalam mencapai sebuah tujuan. Objek penelitian ini tertuju pada tempat transaksi jual beli yaitu pasar Kawasan Makam Gus Dur (KMGD) yang berada di Tebuireng. Penelitian mengenai variasi bahasa yang berada di pasar Tebuireng hanya fokus meneliti kelompok pedagang.

Penelitian ini menarik untuk dilakukan karena terdapat beberapa bahasa yang digunakan di pasar tersebut. Pedagang dan pembeli yang berada di pasar tersebut menggunakan dua sampai tiga bahasa, akan tetapi bahasa yang lebih dominan diucapkan adalah bahasa Jawa karena pada kelompok pedagang di pasar KMGD ratarata menggunakan bahasa jawa, meskipun bahasa yang digunakan lebih dominan bahasa Jawa tetapi para pedagang juga menggunakan bahasa yang lainnya seperti bahasa Indonesia.

\section{LANDASAN TEORI}

1. Variasi Bahasa

Variasi bahasa yakni sebuah pembahasan mengenai bahasa dalam kajian sosiolinguistik, Kridalaksana (Chaer, 2010: 61) mendeskripsikan mengenai sosiolinguistik selaku cabang linguistik yang berupaya memaparkan ciri-ciri variasi bahasa dan memilih hubungan timbal balik dari variasi bahasa dengaan sosial masyarakat. Kevarian ini akan semakin banyak kalau bahasa dipakai oleh penutur yang jumlahnya sangat banyak,dan didalam suatu lingkup yang luas,dalam hal varian bahasa ataupun ragam bahasa ada dua pandangan yakni pertama variasi bahasa atau ragam bahasa, dilihat seperti akibat adanya keberagaman sosial penutur bahasa dan keragamaan fungsi bahasa. Andai kata pengucap bahasa yakni komunitas yang homogen baik etnik, status sosial maupun lapangan pekerjaanya, bahwa variasi atau keragaman itu tidak pernah ada, artinya bahasa menjadi seragam. Kedua, variasi atau ragam bahasa telah ada guna melengkapi fungsinnya sebuah pandangan yanng diterima atau pun ditolak,variasi atau ragaam bahasa dapat digolongkan keberagaman sosial dan fungsi aktifitas didalam masyarakat sosial. Variasi bahasa terbagi menjadi empat segi yakni seperti berikut:

a) Variasi bahasa dari segi penutur

Variasi bahasa dari segi penutur ada tiga yakni, pertama variasi bahasa dari segi penuturnya yakni variasi bahasa yang disebut ideolek yaitu variasi bahasa yang memiliki sifat perseorangan. Menurut konsepsi ideolek ini masing-masing orang memiliki variasi bahasa atau ideoleknya sendiri. biasanya variasi ideoleknya ini bertepatan dengan warna suara, diksi, gaya bahasa, susunan kalimat dan sebagainnya tapi warna suara lebih pengaruh sehingga jika kita layak dekat dengan orang tersebut, mendengarkan suara tanpa melihat orangnnya pun kita sudah mengenali dirinya, mengetahui idieolek orang dari pembicaraanya memang lebih gampang daripada melalui karya tulisannya. Kedua variasi bahasa berdasarkan penutur ialah disebut dialek yaitu variasi bahasa dituturkan oleh kelompok pembicara yang jumlahnya banyak yang ada disatu tempat juga lingkup area tersendiri.

Variasi bahasa berdasakan 
penuturnya yang ketiga yaitu kronolek atau dialek berhubungan dengan waktu ialah variasi bahasayang dipakai mayarakat sosial disuatu masa tetentu. Seumpa variasi bahasa Indonesia pada tahun tiga puluhan, variasi bahasa padatahun lima puluhan dan tentunya variasi bahasa yang digunakan pada masa sekarang. Variasi bahasa tersebut tentu beda, baik dari segi lafal, ejaan,morfologi maupun sintaksis. Keempat yakni variasi bahasa berdasarkan penuturnya disebut sosiolek dialek social yaitu variasi bahasa bekenaan dengan status, golongan, dan kelas sosial para penuturnya.

Perbedaan bahasa mereka terutama karena faktor lingkungan tempat bekerja. Berdasarkan kebangsawanan, dapat kita lihat variasi bahasa yang berkenaan dengan tingkattingkat bangsawan. BahasaJawa, bahasaBali, bahasa Sunda mengenalvariasi kebangsawanan ini, tetapi bahasa Indonesia tidak.

b) Variasi Bahasa dari segi Pemakaian

Variasi berdasarkan dengan penggunaanya, pemakaian atau fungsinya disebut fungsiolek, ragam atau register. Nabban (Chaer, 2010: 68). Varasi bahasa berdasarkan bidang pemakaian ialah mengenai bahasa itu dipakai untuk keperluan atau bidang apa. Misalkan dalam bidang jurnalist, militer,pertanian, perdaganngan, pendidikan dan keilmuan. Variasi bahasa dalam hal ini yakni dalam bidang kosakata. Berdasarkan ragam bahasa Jurnalis juga mempunyai ciri tersendiri yakni mempunyai sifat kesederhana, komunikatif,dan singkat. Sederhana sebab harus dipahami dengan mudah, komunikatif karena jurnalistik harus menyampaikan berita secara tepat dan ringkas karena keterbatasan ruang dalam media cetak dan terbatasanya waktu (dalam media elektronik). Berdasarkan bahasa kemiliteran dikenal dengan ciri yang singkat lalu mempunyai sifat tegas, sesuai dengan tugas dan kehidupan kemiliteran yang penuh dengan disiplin dan instruksi. Berdasarkan bahasa ilmiah yang juga disebut degan cirinya yang lugas, jelas, dan bebas dari keambiguan, serta segala macam metafora dan idiom. karena bahasa ilmiah harus memberikan informasi keilmuan secara jelas, tanpa ada keraguan akan makna dan terbebas dari kemungkinan tafsiran makna yang beda.

c) Variasi Bahasa dari Segi Keformalan Berdasarkan tingkat

keformalanya, Martin Joos (Chaer, 2010:70) yang menulis didalam bukunya The Five Clock menbagi variasi bahasa atas lima gaya (Inggris; Style) yaitu gaya atau ragam beku (frozen), resmi (formal), gaya atau usaha (konsuliatif), gaya atau ragam santai(casual), dan akrab(intimate). Akan dipaparkan sedikit di pembahasan ini mengenai lima ragam variasi bahasa dari segi keformalan. Pertama, ragam beku ialah variasi bahasa yang sangat formal dan dipakai dalam situasi khidmat dan upacara resmi, misal dalam upacara kenegaraan, khutbah di masjid, akte notaris dan lainnya. Kedua, ragam resmi atau formal yakni variasi bahasa ini dipakai dalam pidato negara, rapat dinas, surat- menyurat. Ragam resmi ini sama halnya dengan ragam baku atau standart yang bisa diguakan dalam formal situation dan tidak digunakan dalam situasi tidak resmi. Ketiga, ragam usaha atau konsultatif adalah variasi bahasa yang lazim digunakan dalam pembicaraan biasa di sekolahan dan rapat-rapat. Keempat, ragam santai atau kasual adalah variasi bahasa yang di gunakan dalam situasi tidak resmi untuk berbincangbincang dengan keluarga atau teman karib. Ragam santai ini banyak mengunakan bentuk alergo, yakni bentuk kata atau ujaran yang dipendekan. Kelima, 
ragam akrab atau ragam intim adalah variasi bahasa yang biasa digunakan oleh penutur yang hubungannya sudah akrab, seperti antaranggota keluarga, antarteman yang sudah karib. Ragam ini ditandai dengan penggunaan bahasa yang tidak lengkap, pendek-pendek dan dengan artikulasi yang seringkali tidak jelas. Hal ini terjadi karena diantara partisipan sudah ada saling pengertian dan memiliki pengetahuan yang sama.

d) Variasi Bahasa dari segi Sarana Variasi bahasa dapat kita amati dari segisarana atau jalur yang digunakam. Dalam halitu dapat di sebut ada ragam tulis atau ragam dalam $b$ ahasa yang memakai sarana/alat tertentu misal, dalam telepon juga bertelegram.

2. Diksi

Diksi adalah suatu pilihan kata yang tepat dan selaras dengan penggunaanya dalam meyampaikan sebuah gagasan atau cerita yang meliputi gaya bahasa, ungkapan, pilihan kata dan lain-lain sehingga didapatkan efek sesuai dengan yang diinginkan, menurut Gorys Keraf (2008:30) diksi terbagi menjadi tiga ciri yakni:

a) Pilihan kata atau diksi mencakup pengertian kata-kata mana yang dipakai untuk menyampaikan gagasan, bagaimana membentuk pengelompokkan kata-kata yang tepat.

b) Pilihan kata atau diksi adalah kemampuan membedakan secara tepat nuansa-nuansa makna dari gagasan yang ingin disampaikan dan kemampuan menemukan bentuk yang sesuai atau cocok dengan situasi dan nilai rasa yang dimiliki kelompok masyarakat pendengar.

c) Pilihan kata yang tepat dan sesuai hanya dimungkinkan penggunaan sejumlah besar kosa kata atau perbendaharaan kata bahasa.

Diksi atau pilihan kata adalah kemampuan sesorang membedakan secara tepat nuansa- nuansa makna sesuai dengan gagasan yang ingin disampaikannya dan kemampuan tersebut hendaknya disesuaikan dengan situasi dan nilai rasa yang dimiliki oleh sekelompok masyarakat, pendengar atau pembaca Widyamarta (1990: 45). Jadi dapat disimpulkan bahwa pengertian diksi ialah pilihan kata yang tepat untuk menyampaikan sebuah gagasan atau cerita yang ingin disampaikan untuk pembaca atau pendengar yang disesuaikan dengan situasi yang ada disekelompok masyarakat tersebut.

\section{METODE PENELITIAN}

Bentuk penelitian yang digunakan oleh pengkaji yakni penelitian deskriptif kualitatif dengan cara langsung terjun dilapangan tempat objek yang akan diteliti, karena peneliti disini mendeskripsikan sebuah keadaan. Adapun pengertian dari deskriptif kualitatif adalah penelitian yang menggunakan metode pengumpulan data berdasarkan apa yang dilihat untuk mengungkapkan sebuah fakta yang ada, keadaan, fenomena yang sedang berlangsung. Adapun kategori riset ini berkarakter lapangan, dimana pengkaji harus terjun langsung ke tempat penelitian dan tujuan penelitian lapangan ialah untuk mengumpulkan, menggolah dan menelaah data dari sumber tempat penelitian. Penelitian dilakukan di pasar KMGD Tebuireng Jombang. Waktu penelitian dilaksanakan yakni pada bulan Desember 2019.

Subjek dalam penelitian ialah pedagang makanan, aksesoris dan pakaian yang berada di pasar KMGD. Sedangkan objek penelitian ini mengenai variasi bahasa yang digunakan oleh pedagang dalam jual beli di pasar KMGD Tebuireng Jombang. Sumber data dari riset ini adalah subjek awal data yang diperoleh. Sumber data penelitia adalah faktor berharga yang menjadi pertimbangan untuk menentukan metode penulisan data. Sumber data yakni sumber yang diperlakukan untuk mengumpulkan data yang diperlakukan dipenelitian. Data penelitian dikumpulkan baik dengan hasil 
Jurnal DISASTRI (Pendidikan Bahasa dan Sastra Indonesia)

Volume 3, Nomor 1, April 2021| P-ISSN : 2716-4114 | E-ISSN: 2722-3329

observasi, maupun dokumentasi, biasanya data yang harus dikumpulkan adalah data primer dan data sekunder.

\section{PEMBAHASAN}

Berdasarkan hasil penelitian di pasar KMGD Tebuireng Jombang bahwa dalam ungkapan tutur kata yang diucapkan oleh pedagang terdapat beberapa diksi tersendiri yang mereka gunakan dalam menjual barang dagangannya masingmasing, pemilihan kata atau diksi ini sangat mempengaruhi terhadap pekerjaan mereka, karena dengan diksi atau pemilihan kata bisa menetukan terjualnya barang dagangan. Dalam penelitian ini diksi atau pemilihan kata dan ungkapan yang mereka pakai lebih dominan memakai diksi atau ungkapan dari bahasa jawa. Berikut ini beberapa kutipan yang menggambarkan diksi dan ungkapan bahasa jawa yang dipakai pedagang.

\section{(1)}

\section{Kode Data: FK1.DUBS.PA.13}

Data tuturan: "Aku wingi tuku bros iki, terus jare bojoku dikongkon nukerno gak popo a?" (saya kemarin membeli hiasan hijab ini, terus kata suamiku disuruh menukarkan tidak apa- apa?)

(2)

Kode Data: FK2.DUBS.PM.26

Data tuturan: "Wonten seng eco, kurmae benten, enten kaleh macem" (ada yang enak, kurmae beda, ada dua macam)

Konteks:

Pedagang menghadap ke pembeli sambal menjelaskan jenis kurma.

Berdasarkan data (1) dan (2) dengan kode FK1. DUBS.PA.13 dan FK2.DUBS.PM.26. diatas didapatkan suatu diksi dan ungkapan bahasa jawa yang digunakan dalam tutur bahasa pedagang, karena dalam lingkup pasar KMGD yang berada di Jombang tersebut kebanyakan para pedagang menggunakan tutur bahasa jawa yang lebih enak didengar,dilihat dari tutur bahasa yang dipakai oleh pedagang ungkapan dan diksi mengarah pada bagaimana membentuk pengelompokan kata yang tepat yang digunakan oleh pedagang dalam melakukan interaksi jual beli yang berada di pasar KMGD Tebuireng Jombang. Hal tersebut sesuai dengan pendapat Keraf (2008:30) yang menyatakan didalam salah satu ciri-ciri diksi yakni pilihan kata atau diksi mencakup pengertian kata- kata mana yang dipakai untuk menyampaikan gagasan dan bagaimana membentuk pengelompokkan.

Berdasarkan hasil penelitian juga didapatkan tutur bahasa pedagang yang tidak hanya memakai bahasa jawa tetapi juga ada pedagang yang memakai bahasa indonesia karena faktor pembeli yang menawar barang dagangannya dengan memakai tutur bahasa indonesia. Diksi dan ungkapan yang digunakan oleh pedagang juga mempengaruhi laku tidaknya barang yang dijual, maka dari itu sang pedagang terkadang juga mengikuti bahasa sang pembeli. Berikut ini beberapa kutipan yang menggambarkan mengenai diksi dan ungkapan bahasa indonesia para pedagang.

(3)

Kode Data: FK3.DUBS.PA.9

Data tuturan: "Yang mana ya mbak, yang ini ya mbak?"

Konteks: Pedagang mengambilkan aksesoris yang ditunjuk oleh sang pembeli.

(4)

Kode Data: FK4.DUBS.PA.10

Data tuturan: "Bisa dicampur mbak".

Konteks: Pedagang menunjuk aksesoris yang bisa dicampur dengan harga seperti itu. 
Berdasarkan data (3) dan (4) dengan kode FK1. DUBS.PA.9 dan FK2.DUBS.PM.10. diatas didapatkan suatu diksi dan ungkapan bahasa indonesia yang digunakan dalam tutur bahasa pedagang yakni diksi dan ungkapan bahasa indonesia, pedagang menyesuaikan bahasa yang digunakan oleh pembeli, ungkapan dan diksi tersebut mengarah pada bagaimana membentuk pengelompokan kata yang tepat yang digunakan oleh pedagang dalam melakukan interaksi jual beli yang berada di pasar KMGD Tebuireng Jombang. Hal tersebut sesuai dengan pendapat Keraf (2008:30) yang menyatakan didalam salah satu ciri-ciri diksi yakni Pilihan kata atau diksi mencakup pengertian kata-kata mana yang dipakai untuk menyampaikan gagasan dan bagaimana membentuk pengelompokkan katakata yang tepat.

Berdasarkan hasil penelitian juga didapatkan tutur bahasa pedagang yang memakai bahasa indonesia untuk menjawab sang pembeli yang memakai bahasa madura guna menawar barang dagangannya. Berikut ini beberapa kutipan yang menggambarkan mengenai diksi dan ungkapan para pedagang dan pembeli.

(5)

Kode Data: FK5.DUBS.P.15

Data tuturan: "Berempah bak?"

(berapa harganya kak?)

Konteks: Pembeli menanyakan harga baju yang dipegangnya

(6)

Kode Data: FK6.DUBS.PB.15

Data tuturan: "Empat Puluh"

Konteks: Pedagang merapikan baju sambil memberitahu harga baju tersebut.
Berdasarkan data (5) dan (6) dengan kode FK1. DUBS.PA.9 dan FK2.DUBS.PM.10 diatas didapatkan suatu diksi dan ungkapan bahasa indonesia yang digunakan dalam tutur bahasa pedagang yang sedang merespon seorang pembeli yang menggunakan tutur bahasa madura, akan tetapi pedagang lebih memilih menggunakan bahasa indonesia, karena pedagang tersebut memiliki kemampuan yang bisa membedakan diksi dan ungkapan apa yang cocok untuk merespon balik pertanyaan dari pembeli dengan melihat situasi. Hal tersebut sesuai dengan pendapat Keraf (2008:30) yang menyatakan didalam salah satu ciri-ciri diksi yakni kemampuan membedakan secara tepat nuansa-nuansa makna dari gagasan yang ingin disampaikan dan kemampuan menemukan bentuk yang sesuai atau cocok dengan situasi dan nilai rasa yang dimiliki kelompok masyarakat pendengar.

\section{SIMPULAN}

Berdasarkan hasil penelitian yang sudah dilakukan oleh peneliti mengenai karakter interaksi jual beli di pasar KMGD Tebuireng Jombang dapat disimpulkan bahwa ungkapan bahasa pedagang yang digunakan yakni ada diksi dan ungkapan bahasa Jawa, Indonesia, dan Madura.

\section{DAFTAR PUSTAKA}

Basir. Udjang Pr. M. 2010. Menulis Artikel: Konsep Dasar dan Aplikasi.http://www.academi.edu /38109634/Men ulis Artikel Konsep Dasar dan Aplikasi (Diakses pada taggal 16 Februari 2020).

Chaer, Abdul dan Leonie Agustina. 2010. Sosiolinguistik Perkenalan Awal. Jakarta: Rineka Cipta.

Hariadi, Try. 2014. Penggunaan Bahasa dalam Transaksi Jual Beli di warung "Bude Sarmi". Skripsi. Pontianak: IKIP-PGRI. 
Keraf, Gorys. 2008. Diksi dan Gaya Bahasa. Jakarta: PT Gramedia Pustaka Utama.

Nurgiyantoro, Burhan. 2015. Teori Pengkajian Fiksi.

Yogyakarta: Gajah Mada University Press.

Perwira, Asa Aga. 2013. Variasi Bahasa Sapaan Jual Beli Pedagang pasar Klitikan di Semanggi. Skripsi. Surakarta: Universitas
Muhammadiyah.

Sugiyono. 2016. Metode Penelitian Kuantitatif, Kualitatif, dan $R \& D$. Bandung: Alfabeta.

Siswanto, dkk. 2012. Pengantar Linguistik Umum.

Yogyakarta: Media Perkasa.

Suwito. 1982. Pengantar Awal Sosiolinguistik, Teori dan Problema. Surakarta: Hwanary Offset. 